\title{
Pele de animal, pele de desejo, pele de tristeza
}

\author{
Loraine Oliveira \\ Universidade de Brasília (UnB)
}

\section{Das minhas peles}

A pele macia e branca da Ninfa homérica. A mão branca de Isolda. A pele pelo macia da marta. Pelagem cobiçada, envergada com orgulho por uma mulher em um salão cheio de luzes, tapete vermelho escuro com círculos bege, um homem de meia idade, normalmente feio, mas devidamente ataviado. Até parece bonito. Até parece alguém. Mas é um ninguém qualquer que ladeia a mulher da pele. Caminham lentamente, um sorriso triunfante em cada lábio, em cada ruga pequena, em cada fio tingido dos cabelos da mulher, em cada fio embranquecido da barba do homem. Olho em volta e certa tristeza me invade. Não é uma, são várias mulheres envergando peles. São animais mortos cobrindo corpos de desejo. Mortes flutuando sobre o tapete. Mortes marrons, pretas, brancas, castanhas. Garçons se entremetem pelo caminho com suas bandejas prateadas. Taças de champagne, cheiro de carnes e massa de salgadinho. Cheiro de perfume italiano e francês, cheiro de esnobismo, de despudor e de risadas agudas. Saio entorpecida. Saio chorando. Entro em crise, choro longamente jogada na cama, em crise contra a humanidade que mata animal para tirar a pele, que faz da pele um desejo, do desejo mil tristezas.

Aprendi que o pincel de pelo de marta é infinitamente superior ao pincel de cerdas sintéticas. Um dia ganhei um pincel de pelo de marta. Cabo amarelo, adequado para a minha mão. Pelo macio, traço preciso. Tinha pena de mergulhar na tinta e passar na tela. Ficava olhando o pincel e tentando figurar mentalmente a marta. Não tinha internet na época. Não tinha computador em casa, e se bem lembro, nem na faculdade. Ou talvez na faculdade 
tivesse tão poucos que passavam despercebidos. Mas muita gente tinha pincéis de marta. Muita gente tratava seus pincéis de marta como um utensílio qualquer da pintura. $\mathrm{O}$ meu não, ele era meio sagrado. Talvez não só por ser de bicho, mas porque eu não conseguisse imaginar a marta, e nem saber de onde saíra o pelo do pincel. Do rabo? Do torso? Meu pincel de marta morreu. A melancolia com que ele ficava, sem uso, na latinha de pincéis talvez o tenha matado.

Pele de bicho raro, talismã.

Sei bem que essa história do pincel de pelo de marta soa ridícula. Podem dizer que eu sou uma besta. Aliás, gritem alto. Bem alto: a Loraine é uma besta, uma toupeira, uma burra! Onde já se viu não saber como é uma marta! E riam, riam muito. Façam isso mesmo, transformem os substantivos que nomeiam animais em adjetivos que depreciam gente. Tornem normal a inferioridade do bicho. Porque isso facilita a dominação. E vocês, vocês aí mesmo, que me acham uma besta, vocês estão todos dominados. Dominados pela linguagem, pelo desejo, pela pele escudo protetora.

Meu pequeno mundo de estudante de artes era um mundo sem conexões. Nada parecia formar um todo. O todo que define uma vida humana dita normal. Ou ao menos, era isso que eu sentia. O pelo do pincel era o mesmo do casaco? Olhando minha gata, que tinha um rabo bem peludo, e um pelo bem espesso, eu conseguia imaginar que aquele pelo valioso tinha sido cortado do rabo da marta. A marta era uma gata peluda sem raça definida. Ocorriame que as martas eram mortas aos montes para fazer roupas, e que partes de peles de casaco viravam pelo de pincel, abastecendo outra indústria de luxo, deleite e prazer. Claro que me ocorria! Mas eu não conectava. Continuava olhando a gata sentada no parquet do atelier.

Quando não se faz a conexão, a coxa e a sobrecoxa na bandeja de isopor coberta com plástico não pertencem à galinha. O salmão não é carne. O patê de fois gras é uma massa de cor fugidia, que vem da França, e é chique. Nada tem a ver com o ganso. 
E aquelas coisinhas pretas minúsculas, o caviar, de que é feito mesmo? Parece uma frutinha. Será que é fruto do mar? Fruto do mar também é carne.

\section{Da pele de onagro}

O onagro é um tipo de jumento selvagem que vem dos desertos orientais. Ele é indomável. Existe em francês o substantivo onagre, e Balzac o utiliza no seu romance La Peau de Chagrin. O bom uso do método de historiadora da filosofia antiga me faz interrogar sobre quantas e quais são as ocorrências de onagre e de chagrin, assim como de seus respectivos cognatos, no romance. Uma vez elencados, devo analisar passagem a passagem, não sem antes ter lido e fichado o romance inteiro em francês, claro. Da análise minuciosa de cada passagem individualmente, do seu cotejo e do conjunto das passagens do mesmo termo e seus cognatos, devo chegar a certas hipóteses. Então me voltarei novamente para o texto, e passarei a estudar seus comentadores, sempre com o texto aberto ao lado, e meus fichamentos ao alcance do olhar. A essa altura o livro estará repleto de anotações a lápis e etiquetas coloridas sinalizando passagens importantes para a tese a que me propus. Le bon usage...

Uma passagem notável é aquela em que o cientista descreve o onagro para Raphael de Valentin. E nesse trecho, em que o exotismo e a superioridade do animal aparecem, Balzac não usa chagrin, mas sim onagre. Vejamos, listando, parafraseando e traduzindo, como o animal é qualificado na passagem em tese. Magnífico animal, cheio de mistérios. Seus olhos possuem uma espécie de tapete refletor, ao qual os orientais atribuem o poder da fascinação. Seu vestido (sa robe) é mais elegante e mais lustroso que a dos nossos mais belos cavalos. Sua lã tem algo de macio, de ondulante. Sua visão iguala em precisão a visão humana. Possui uma coragem extraordinária. Defende-se com nítida superioridade das bestas mais ferozes. Sua rapidez só é comparável ao voo dos pássaros. Um onagro mataria, em uma corrida, os melhores cavalos persas ou árabes. Enfim, um onagro domado vale somas imensas. 


\section{Da minha tristeza}

Nos final dos anos 80 ganhei uma jaqueta de pele sintética com estampa de oncinha. Achei escandalosa e inadequada para a vidinha em preto que eu levava. Apesar de quentinha e confortável, não podia usar. Mas usei agora, recentemente, na época do episódio das mulheres de peles. A jaqueta é descaradamente sintética. Por isso, pretendo usá-la ainda mais vezes, como uma forma de resistência à vil elegância dos casacos de pele natural, ao consumismo, aos modismos, a tudo que se relaciona com a cultura e com o bom gosto que matam para sobreviver. Meu casaco agora não deixa de ser uma ode contra a violência que bate no coração da cultura - com toda a pieguice da metáfora. A violência que faz a cultura ser o que ela é. Não gosto nem um pouco dessa ideia messiânica segundo a qual cultura é uma coisa boa. Então matar bichos para comer é uma coisa boa. Criar bichos para matar é uma coisa boa. Pouco importa se é matar para comer, ou para vestir, ou para rejuvenescer a pele, ou para gerar mais lucro para a indústria farmacêutica, ou para promover o progresso da ciência, ou para empalhar e vender a algum excêntrico. Isso tudo é cultura. Assim como as metáforas animais que servem para desabonar pessoas, tais como anta, burro, toupeira, vaca, cadela, cachorro, viado, perua, cavalo, galinha, águia, rato, lesma, porca, porco, cobra, naja... Não é necessário explicar o sentido de cada metáfora, nem mesmo mostrar os referentes ausentes. Os leitores lusófonos saberão perfeitamente do que se trata em cada caso. Diante disso, devo me opor e resistir a essa cultura. E como não sou do tipo que faz manifestos, que segue coletivos, ou que faz uso da internet para incitar a revolução, minha resistência e minha oposição serão apenas estéticas. Casaco sintético antigo com bota sintética usada. E não serei vista como maltrapilha, apenas como uma dessas intelectuais ou artistas que andam por aí anacronicamente vestidas, falando de coisas estranhas, vivendo de modo bizarro. É assim, olhando e classificando, que a cultura violenta e engole quem quer resistir a ela. Legitimando uma economia dos sentidos, em que o animal é irracional e desprovido de senciência. 
O olhar violenta, a classificação engole. Sim, escrevi isso. E quis escrever isso naquele paralelismo. Estou poupando trabalho ao leitor desavisado e tentando mitigar o excesso de interpretação.

\section{Dos desejos de Raphael}

Um banquete, talheres de prata, ricos convivas. Um bacanal. Vinhos de todos os tipos, carnes de todos os bichos, mulheres de todas as estirpes. Foi o primeiro desejo de Raphael para o talismã; a pele de chagrin o atendeu de imediato.

Raphael queria morrer. E por isso ele ganhou a pele mágica. Naquele dia, seu maior e mais fundo desejo, em última análise, era a morte. O desejo pelas coisas e pelo sucesso substituiu-se ao desejo pela morte e tão logo a pele passou a the proporcionar imediata realização de cada desejo fútil, de cada desejo enunciado, pensado. Desde uma refeição qualquer, até uma grande soma de dinheiro. E desejou mulheres, conquistou o grand monde, foi convidado à mesa dos ricos. A cada desejo, a pele encolhia proporcionalmente à medida do desejo. Raphael ia perdendo vida e ganhando prazeres. O desejo, contudo, encontrou a dor. Quando Raphael, já tendo desperdiçado enormemente a pele - ela então cabia na palma da mão - deu-se conta de qual era seu grande desejo. Seu grande e fundo desejo não era mais a morte. No entanto, não havia nada além da morte a esperar. A pele por pouco não se acabara. De pele de desejo, tornou-se pele de tristeza.

Raphael não passava de um pobre coitado. Um ninguém, um qualquer no Palais Royal, na pensãozinha barata da mãe de Pauline, nas páginas do livro malsucedido que escreveu, na vida. Dirá um leitor apressado de Balzac: tão ninguém, que sequer consegue se suicidar! Será? Consegue, sim, e de forma sofisticada. O desejo suicida de Raphael, desejo pela morte precoce, por um fim à vidinha medíocre que levava, é atendido por um antiquário que lhe apresenta a pele talismânica. Mais precisamente, quem realiza seu voto é a capacidade da pele de atender aos desejos em troca da vida. Cada encolhimento da pele representa uma 
diminuição no tempo de vida do detentor. Cada desejo, portanto, é um pequeno suicídio anunciado. Chagrin! O animal exótico tristeza se converte em pele de desejo morte. A morte do animal é a morte daquele que carrega sua pele.

Raphael, por fim, quis amar. Amar Pauline, a pura. Pauline, figura antitética da sociedade, representada por Feodora, a mulher sem coração. Evidentemente não é possível mais viver para amar, quando se vai morrendo por desejos mundanos. Raphael desejou tão ardentemente Feodora, tão vingativamente, que atraiu para si o desejo de vingança. E a sociedade riu da sua cara. Um riso gostoso, descarado. O tripudiou, o venceu. Esgotado e desvalido, Raphael não tinha mais tempo para amar e ser amado. A pele pequeninha anunciava o trágico desfecho.

\section{Animal tristeza}

Chagrin! Animal exótico que se converte em tristeza, pelo desejo de morte.

Nenhum dos cientistas chamados insistentemente por Raphael para reverter o efeito da pele obtêm sucesso. Chagrin! A pele de onagro vence a ciência. A pele de tristeza é impermeável à ciência. A cultura é a vestimenta da pele de tristeza. Bicho pele bicho comida. Bicho social. O irracional, o servil, o metafórico, o testado. O repertório dos objetos semoventes. Isso é tratar os animais com leviandade. Alimento, proteção e força? Carnismo, moda, indústria farmacêutica. Em uma palavra: exploração.

Pele de onagro sintética, carne transgênica. Vinhos de todos os tipos. Caviar e salmão. Talheres de prata, taças de cristal. À mesma mesa ricos convivas. Mulheres sintéticas de todas as estirpes. Homens genéricos. É isso que a cultura masca, engole e regurgita na nossa cara.

A pele balzaquiana simboliza a tristeza de um homem, quiçá de uma cultura. A sociedade hoje não pode ver; a ciência não quer mostrar! O animal sente e sabe. É. 
dasQuestões, n.2, fev./maio 2015

Et la littérature, et la philosophie? Peuvent-elles attraper la peau?

Quelle peau? Celle du désir ou celle de l'animal?

La peau de chagrin. 